СУЧАСНІ ТЕХНОЛОГІЇ ФОРМУВАННЯ КРЕАТИВНОЇ ОСОБИСТОСТІ МАЙБУТНЬОГО ВЧИТЕЛЯ ІНОЗЕМНОЇ МОВИ В УМОВАХ ЗМІШАНОГО НАВЧАННЯ

\title{
MODERN TECHNOLOGIES OF CREATIVE PERSONALITY FORMATION OF THE FUTURE FOREIGN LANGUAGE TEACHER IN A BLENDED LEARNING ENVIRONMENT
}

матеріали дослідження розкривають питання про особливості застосування сучасних технологій навчання з метою розвитку креативної особистості сучасного вчителя іноземної мови в умовах змішаного навчання. Проаналізовано сучасний процес фрормування іншомовної професійної компетентності майбутніх учителів іноземної мови (на матеріалі англійської мови) в умовах дистанційної освіти. Стрімке входження новітніх інформаційно-комунікаційних технологій в освітній простір кардинально вплинуло на всю систему української освіти, позначившись на їі змісті, соормах, методах і підходах до навчання, що зумовило зміну вимог до сучасного учня/студента. Автором наголошено, що профресійна підготовка майбутнього вчителя іноземноі мови вимагає сучасного креативного підходу. Актуальність проблеми дослідження визначається тим, що нині існує безліч методик, які базуються саме на введенні креативного компонента у зміст навчання іноземної мови. Мета дослідження полягає у вивченні і теоретичному обгрунтуванні формування креативної особистості майбутнього вчителя іноземної мови в умовах змішаного навчання із застосуванням різних інноваційних технологій у закладах профресійної освіти (університет, ораховий коледж). Автором представлено комплекс мультимедійних додатків, інформаційних сайтів і новітніх технологій для фрормування іншомовної професійної комунікативноі компетениії студентів в умовах змішаної форми навчання під час дистанційної форми здобуття освіти. Автор дослідження дійшов висновку, що такий комплекс сучасних інноваційних технологій в умовах змішаної форми навчання здатний підвищити ефективність та інтенсивність освітнього процесу, мотивацію до вивчення іноземної мови забезпечити формування креативної особистості, правильність навчальних дій; розвинути самостійність і розширити досвід творчої діяльності студентів.

Ключові слова: вчитель іноземної мови, готовність до педагогічної діяльності, дистаниійне навчання, змішане навчання, мультимедійні технології, креативна особucmicmb.

The research materials reveal the peculiarities of the use of modern technologies in order to develop the creative personality of a modern foreign language teacher in a blended learning environment. The modern process of foreign language professional competence formation of future foreign language teachers (on the material of English language) in the conditions of distance education is analyzed. The rapid entry of the latest information technologies has dramatically affected the entire system of Ukrainian education, affecting its content, forms and methods of teaching, which has led to a change in the requirements for the modern student. The author emphasizes that a modern student, namely a future foreign language teacher, requires a modern creative approach to training. The urgency of the research problem is determined by the fact that today there are many methods of teaching a foreign language, which are based on the inclusion of a creative component in the content of foreign language teaching and its position in terms of various aspects of human activity. The purpose of the study is to investigate and theoretically substantiate the formation of the creative personality of the future teacher of foreign philology in a blended learning environment using different innovative technologies in educational institutions (university, vocational college). The author presents a set of multimedia applications, information sites and the latest technologies for the formation of communicative competence of students in a mixed form of learning. The author of the study concludes that such a set of modern technologies in a mixed form of learning has the ability to increase the efficiency of the educational process; formation of creative personality; ensuring the correctness of the training actions of each user; raising awareness before learning a foreign language; independence of practical activity of students.

Key words: foreign language teacher, readiness for pedagogical activity, distance learning, blended learning, multimedia technologies, creative personality. навчально-реабілітаційна Академія» Запорізької міської ради

Постановка проблеми у загальному вигляді. Стрімкий розвиток суспільства впливає на всі сорери життя людини, і система освіти не $€$ виключенням. Модернізація професійної підготовки майбутнього вчителя іноземної мови, швидкі темпи оновлення стандартів професійної діяльності, інтенсивний розвиток інформаційного суспільства, реальні запити роботодавців стали передумовою фрормування низки вимог до фрахівців, які до того ж постійно змінюються. Сучасний учитель постає не тільки перед необхідністю адаптуватися до нових умов життя, але й активно, творчо пізнавати навколишню дійсність, впевнено діяти у непередбачуваних ситуаціях. Задля того, щоб долати труднощі, знаходити інноваційні шляхи вирішення педагогічних іншомовних проблем, бути успішним, він має активізувати свій творчий потенціал, повною мірою проявити власну креативність. Остання $€$ творчою здібністю, що виступає потужним чинником розвитку 
особистості, визначає її здатність до нестандартного мислення і поведінки, а також готовність до неперервної профресійної іншомовної підготовки. Перед практичною освітою постає завдання виховання креативної особистості, здатної до творчої діяльності у різних сорерах життя [5, с. 162]

Загальновідомим фрактом $€$ те, що саме іноземна мова сприяє активізації іншомовних творчих здібностей як викладача, так і студента (традиційних учасників освітнього процесу). Головна проблема викладання полягає у виборі фрорм, методів і засобів роботи на заняттях англійської мови, які стимулюватимуть розвиток творчості студентів і спонукатимуть до позитивного самовизначення під час фрормування особистісних якостей та об'єктивної самооцінки. Сучасна освіта має спрямовуватися на поєднання інтелектуальних і творчих здібностей, умінь і навичок із найбільш посиленим використанням ресурсів інноваційного середовища.

Метою дослідження є визначення інноваційних методик фрормування креативної особистості майбутнього вчителя іноземної мови в аспекті упровадження змішаного навчання.

Виклад основного матеріалу. Проблему творчої особистості педагога в Україні досліджують науковці Н. Кічук, С. Сисоєва та інші, які вважають, що особистість учителя характеризується спрямованістю на творчість, інтелектуальною активністю [7]. М. Гузик, М. Жалдак, В. Монахов, М. Шкіль та інші надають рекомендації щодо розв'язання творчих завдань. Упровадженню розвивальних творчих ігор присвятили свої праці Д. Балл, Т. Гергей, А. Довіяло та інші науковці. Значну увагу сучасним технологіям, що сприяють фрормуванню творчого потенціалу, приділяли у своїх роботах такі автори, як Н. Бердяєв, Л. Коган, Д. Лихачов, А. Каргін, О. Мотков та інші.

Згідно із концептуальними положеннями системи національного виховання «метою освіти $€$ всебічний розвиток людини як особистості та найвищої цінності суспільства, розвиток її талантів, розумових і фрізичних здібностей, виховання високих моральних якостей; фрормування громадян, здатних до свідомого суспільного вибору; збагачення на цій основі інтелектуального, творчого, культурного потенціалу народу; підвищення освітнього рівня народу; забезпечення народного господарства кваліфікованими фрахівцями» [3]. Сучасний педагог - усебічно та фрундаментально освічена людина, здатна гнучко перебудовувати напрям і зміст своєї профресійної діяльності, наполегливо працювати над власним розвитком і підвищенням освітнього та культурного рівнів, самостійно здобувати потрібні для профресійної діяльності знання, вміння і навички, яка критично мислить, володіє стійкою системою мотивів і потреб соціалізації, готова активно і творчо діяти.
Науковець Ф. Баррон вважає центральними процеси уяви і символізації, визначаючи креативність як внутрішній процес, який спонтанно продовжується в дії, але Дж. Гілфрорд і Е. Торренс розглядають креативність як здатність до творчого (дивергентного) мислення [2]. Своєю чергою А. Маслоу здатність до творчості тлумачить як установку на самореалізацію особистості [10]. Провідну роль у детермінації творчої поведінки відіграють мотивація, цінності, особистісні риси. Творчий процес пов'язаний із самоактуалізацією, повною та вільною реалізацією своїх здібностей і життєвих можливостей. Отже, на думку А. Маслоу, креативність - це творча спрямованість, притаманна всім, але яка втрачається більшістю під впливом системи виховання, освіти і соціальної практики [10]. Д. Богоявленська [1] визначає креативність як глибинну особистісну властивість, яка виражається в оригінальній особистісній постановці проблеми. Водночас науковець констатує, що креативність $€$ загальною особливістю особистості та впливає на творчу продуктивність незалежно від сорери прояву особистісної активності [1].

Процес фрормування майбутнього вчителя іноземної мови (далі - IM) є вкрай важливим і значущим. Цілком логічно, що нині він потребує осучаснення, тому особливої актуальності набуває активне застосування інноваційних підходів і технологій навчання. Аналіз психологічної і педагогічної літератури з питань професійної підготовки вчителів IM переконливо свідчить про те, що декларована проблема розглядається науковцями у низці робіт, де і виокремлено її ключові аспекти, a саме: готовність до професійної діяльності (І. Большакова, Р. Моцик, Л. Потапкіна, Л. Прудка, О. Степаненко, І. Чорна та інші); сучасні педагогічні технології (В. Беспалько, Л. Петренко, О. Пєхота, Г. Селевко та інші); інфрормаційне забезпечення освіти (В. Биков, В. Вінник, Р. Клопов, Т. Коваль, В. Осадчий, Т. Поясок, І. Роберт, Ю. Триус, Л. Хуторська, М. Edwards, А. Ferrari та інші); комбіноване навчання (В. Кухаренко, Н. Рашевська, Дж. Сенер, А. Хейнце, К. Проктер); моделі змішаного навчання (К. Джонсон, К. Крістенсен, Х. Стейкер, М. Хорн, Anders Norberg, Carmen D. Rosell, Chuck Dziuban, Patsy D. Moskal).

Фундаментальний аналіз теоретичних засад окресленої проблеми профресійного розвитку креативної особистості майбутніх учителів ІМ в умовах інфрормаційного суспільства засвідчив, що концепція підготовки таких фрахівців $€$ нерозробленою, зокрема не визначено сучасні стандарти підготовки і шляхи їх упровадження, організації та інтенсиорікації неперервної підготовки вчителів іншомовної освіти; не окреслено організаційнометодичні засади професійної підготовки фрахівців у цій галузі. На нашу думку, особливої уваги заслуговує поняття «змішане навчання», оскільки саме 
така фрорма навчання дає змогу розкрити вагомий потенціал інформаційно-освітніх ресурсів.

Карантинні обмеження посилили виклики, що стоять нині перед закладами освіти України. Потреба у нових підходах до навчання в умовах обмеження кількості аудиторних занять залишається проблемним питанням для значної частини освітянської спільноти. Водночас украй актуальними є такі вимоги до вищої освіти, як доступність та інклюзивність; гнучкість для окремих категорій здобувачів, які працюють, мають дітей тощо; індивідуальна траєкторія навчання здобувача; впровадження дуальної освіти [6]. Змішане навчання (blended learning) - такий тип навчання, який дозволяє слухачам отримувати знання як очно, так і самостійно онлайн, і вирізняється коморортним середовищем та системою комунікації. Змішане навчання є квінтесенцією того кращого, що здатні запропонувати класична і дистанційна системи освіти. I це насправді не новація. Зародилося змішане навчання ще на початку комп'ютерної ери, але популярності набуло у 1990-х, коли дистанційні курси (E-learning) почали активно використовувати для підготовки персоналу великих компаній [8]. Змішане навчання (blended aбо hybrid learning) - це освітній підхід, який поєднує електронне навчання (E-learning) із традиційним очним. Відтак студенти навчаються як у закладі освіти під час аудиторних занять (classroom training), так і самостійно завдяки використанню інформаційноосвітніх технологій (e-learning ) відповідно до рекомендацій і настанов викладачів (рис. 1) [8].

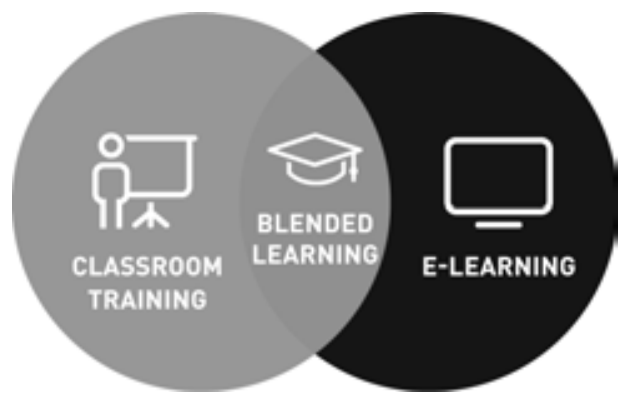

Рис. 1. Схема змісту змішаного навчання (blended learning)

Серед переваг змішаного навчання варто відзначити такі: врахування індивідуальної траєкторії, темпу і можливостей здобувача освіти (робота 3 онлайн-матеріалами дозволяє дотримуватися власного темпу засвоєння програмного матеріалу); створення, а не відтворення знань (можливість відпрацювання практичних ситуацій є характерною особливістю змішаного навчання); спрямованість на самонавчання (студенти здійснюють самостійний пошук навчального матеріалу відповідно до програми дисципліни); спілкування у дистанційному фрорматі як із викладачем, так і з іншими студентами групи (розвиток навичок комунікації, виховання інорормаційної культури, стимулювання активності кожного студента); систематичний орідбек (індивідуальний характер консультування студентів викладачем); гнучкість освітнього процесу (збільшення або зменшення кількості дистанційних елементів відповідно до освітніх потреб, можливість застосування проєктного і дослідницького методів, тестових технологій, навчальна діяльність у малих групах, проведення ділових ігор, організація тренінгів, фрорумів тощо) [4].

Ми порівняли та урахували декілька моделей змішаного навчання, але оптимальними для наших умов вважаємо ті, які запропонували N. Baharun та A. Porter:

- Face-to-face Driver Model (модель віч-навіч) - модель, максимально наближена до традиційного навчання. Оскільки більшу частину заняття викладачі проводять віч-на-віч, онлайн-навчання вводиться для студентів, які не встигають, з метою залучити їх до навчальної діяльності та доповнити заняттями в аудиторії освітнього закладу;

- The Rotation Model (ротаційна, гнучка модель) - модель, за якої викладачі створюють різні навчальні станції, використовуючи цифрові засоби навчання на змінних станціях, водночас вони можуть приділити час спілкуванню віч-на-віч відповідно до конкретних потреб студентів;

- Self-Blend Model (самостійне наповнення навчання) - модель, яка дозволяє студентам брати участь у заняттях, які не входять до загального переліку курсів, завдяки організації онлайнкласів;

- Online Driver (онлайн-навчання, дистанційне навчання) - модель орієнтована тільки на онлайннавчання: студенти працюють із віддалених місць та отримують інструкції і завдання через онлайнплатформи, викладачі виступають у ролі фрасилітаторів і дають змогу студентам зареєструватись і брати участь в онлайн-повідомленнях, якщо їм потрібна додаткова допомога [9].

Ураховуючи сучасний стан організації системи освіти в Україні та карантинні обмеження, найбільшою універсальністю відзначається модель Online Driver. Така модель використовується під час навчання майбутніх учителів IM у разі фрормування іншомовної професійної комунікативної компетентності з урахуванням творчого потенціалу здобувачів освіти на базі Запорізького національного університету (факультет іноземної фрілології) (далі - ЗНУ), відокремленого структурного підрозділу «Економіко-правничий фраховий коледж Запорізького національного університету» (далі ВСП ЕПФК ЗНУ), Педагогічного фрахового коледжу комунального закладу вищої освіти «Хортицька національна навчально-реабілітаційна Академія» (далі - ПФК). Ми наводимо приклад комплексних креативних завдань і додатків наповнення моделі 
змішаного навчання Online Driver для майбутніх учителів IM (на матеріалі англійської мови):

- говоріння: слова до теми, опорні слова, словав'язки (використання PowerPoint Presentation, платфрорма Google Disk), перевірка засвоєного матеріалу (Kahoot), контроль (розробка Mind Map), створення творів (Video Scribe), наукові блоги (Hypotheses), семантизація та актуалізація набутих знань (ISLCollective), проєктна діяльність (web-квест);

- аудіювання: перевірка засвоєного матеріалу (Kahoot), контроль (розробка Mind Map), розробка творів (Video Scribe), семантизація та актуалізація набутих знань (ISLCollective), проєктна діяльність (web-квест);

- читання: перевірка засвоєного матеріалу (Kahoot), контроль (розробка Mind Map), наукові блоги (Hypotheses), семантизація та актуалізація набутих знань (ISLCollective), проєктна діяльність (web-квест);

- письмо: перевірка засвоєного матеріалу (Kahoot), контроль (розробка Mind Map), розробка творів (Video Scribe), наукові блоги (Hypotheses), семантизація та актуалізація набутих знань (ISLCollective);

- робота з англомовними додатками: LinguaLeo, ED Words, Words, Easy ten, Memrise, Anki, FluentU, Hallo Talk, English Grammar Test, Urban Dictionary (платорорми Google Play, App Store);

- робота із додатком Kahoot, Plickers, Survey Monkey (платформи Google Play, App Store) [12].

Серед учасників змішаного навчання проведено опитування щодо доцільності використання такої форми навчання. В опитуванні брали участь 61 студент: ЗНУ - 34, ВСП ЕПФК ЗНУ - 10, ПФК 17. Результати опитування засвідчили, що модель змішаного навчання підтримується студентами (68\%) і сприяє інтенсифрікації творчої діяльності майбутніх учителів іноземної мови (рис. 2) [11; 12].
Наступне запитання дало змогу з'ясувати ставлення і готовність студентів до активного застосування інорормаційних технологій під час змішаного навчання (рис. 3) [11].

Саме такий показник готовності до активного застосування інфрормаційних технології підтверджує ефективність використання інфрормаційноосвітніх ресурсів під час змішаного навчання 3 метою фрормування творчої особистості майбутнього вчителя іноземної мови.

Висновки. Узагальнюючи представлені результати дослідження, ми дійшли висновку, що перехід до змішаної фрорми навчання дійсно сприяє розвитку креативності майбутніх учителів іноземної мови. Прискореного результату вивчення мови можна домогтися завдяки системному використанню творчих завдань і вправ, урізноманітненню форм, методів і засобів навчання. Окрім того, розвиток особистих творчих здібностей і навичок навчально-дослідницької роботи є нині найважливішою потребою студента, причому дослідницька робота ефрективно розвиває креативність як студента, так і викладача.

Креативність виражається у творчому підході викладача і студента до вирішення поставлених завдань. Креативний підхід викладача до освітнього процесу проявляється у постійній роботі з удосконалення змісту аудиторної, дистанційної та самостійної роботи студентів, зокрема у підборі вправ і завдань, які не тільки поглиблюють знання із певної теми, але і вчать аналізувати, порівнювати, узагальнювати тощо. Створення умов для активної творчої діяльності студентів забезпечує розвиток мислення, дає змогу поглибити і розширити знання з іноземної мови та інших фрахових предметів.

Надалі ми плануємо розробити зміст змішаної моделі навчання для базового курсу «Методика викладання іноземної мови».

Чи доцільно, на вашу думку, використовувати змішану модель навчання при підготовці вчителя іноземної мови?

\section{口TAK \\ $\square \mathrm{HI}$ \\ - Частково}

口Вагаюсь відповісти

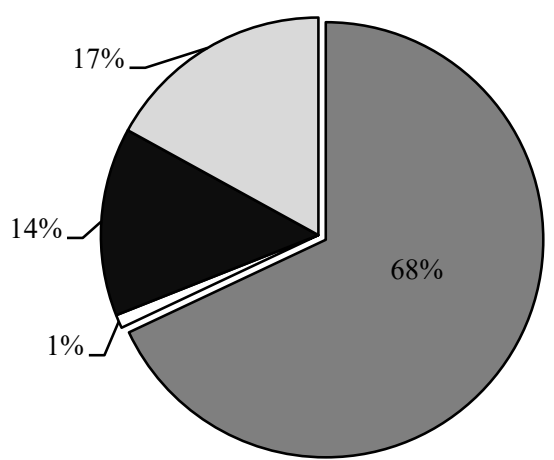

Рис. 2. Приклад відповіді на запитання про доцільність використання змішаного навчання під час формування іншомовної професійної компетентності майбутніх учителів IM 


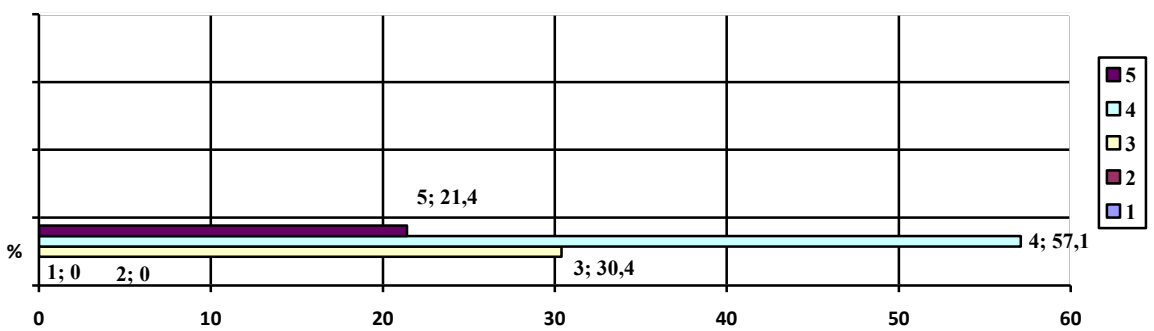

\begin{tabular}{|c|c|c|c|}
\hline № & Значення & $\begin{array}{l}\text { Кіль- } \\
\text { кість }\end{array}$ & $\%$ \\
\hline 1 & $\begin{array}{l}\text { відчуваю труднощі у роботі } 3 \text { комп'ютерною } \\
\text { технікою, не вірю у свої сили і здібності }\end{array}$ & 0 & 0 \\
\hline 2 & $\begin{array}{l}\text { не впевнений, що зможу засвоїти комп'ютерні } \\
\text { технології/змішане навчання }\end{array}$ & 0 & 0 \\
\hline 3 & $\begin{array}{l}\text { відчуваю певні труднощі у засвоєнні комп'ютерних } \\
\text { технологій, але впевнений, що наполегливість і } \\
\text { старанність допоможуть успішно їх подолати }\end{array}$ & 17 & 30,4 \\
\hline 4 & $\begin{array}{l}\text { упевнений у своїх можливостях і відчуваю } \\
\text { задоволення від досягнення успіхів у засвоєнні та } \\
\text { використанні ІКТ у межах змішаного навчання }\end{array}$ & 32 & 57,1 \\
\hline 5 & $\begin{array}{l}\text { не сумніваюсь у своїх можливостях, маю досвід } \\
\text { роботи } 3 \text { ІКТ i можу поділитися ним } 3 \text { іншими } \\
\text { студентами в межах змішаного навчання }\end{array}$ & 12 & 21,4 \\
\hline
\end{tabular}

Рис. 3 Результати самооцінки студентами своїх потенційних можливостей роботи 3 інфоомаційними технологіями

\section{БІБЛІОГРАФІЧНИЙ СПИСОК:}

1. Богоявленская Д.Б. Одаренность и творчество. Одаренный ребенок. 2016. № 5. С. 6-16.

2. Гілсрорд Дж., Торренс Е. Концепція креативності. URL: https://vcf.vn.ua/koncepciya-kreativnosti-dzhgilforda-i-e-p-torrensa/ (дата звернення: 05.11.2021).

3. Про освіту : Закон України від 11.09.2003 № 1158-IV. URL: http://search. ligazakon.ua/l_doc2.nsf/ link1/T031158.html (дата звернення: 18.10.2021).

4. Змішане навчання: шлях до змін. Як змиритися $з$ приходом дистанційних технологій в освітній процес? URL: https://naurok.com.ua/post/zmishanenavchannya-shlyah-do-zmin. (дата звернення: 05.11.2021).

5. Позняк Т. М. Розвиток креативних здібностей особистості. Вісник Чернігівського національного педагогічного університету. Сер. Психологічні науки. 2013. Вип. 114. С. 161-166.

6. Рекомендації щодо організації змішаного навчання у вузах та коледжах. URL: http://life. karpat.in.ua/?p=19610\&lang=uk). (дата звернення: 05.11.2021).

7. Розвиток творчого потенціалу педагога. URL: http://ukped.com/skarbnichka/5701-rozvytoktvorchoho-potentsialu-pedahoha.html. (дата звернення: 03.11.2021).
8. Bailey J. Blended Learning Implementation Guide Version 2.0. Foundation for Excellence in Education., 2013. URL: http://digitallearningnow.com/site/ uploads/2013/10/10/BLIG-2.0-Final-Paper.pdf. (дата звернення: 18.12 2020).

9. Horn M. B. The Rise of K-12 Blended learning. Innosight Institute. 2011. P. 78-112. URL: https://www. christenseninstitute.org/wp-content/uploads/2013/04/ The-rise-of-K-12-blended-learning.pdf (дата звернення: 10.112021 ).

10. Maslow A. H. Motivation and Personality (2nd ed.) N.Y.: Harper \& Row, PSYLIB, 2004. URL: https://www.holybooks.com/wp-content/uploads/ Motivation-and-Personality-Maslow.pdf (дата звернення: 11.11.2021).

11. MeniailoV., ShapranY., ShapranO., SerhiichukO., Bahno Y., Kanibolotska O. Innovative Training of Future Teachers of Higher Education Institutions in the Conditions of Distance Learning. Revista Romaneasca Pentru Educatie Multidimensionala. 2021. Vol. 13 (2). P. 288-303.

12. Miziuk V., Berdo R., Kanibolotska O., Derkach L., Stadnii A. Flipped Learning : Strategies and Technologies in Higher Education. IJCSNS International Journal of Computer Science and Network Security. 2021. Vol. 21, No 7. P. 63-69. 